Original Research Paper

\title{
Analisis Kemampuan Berpikir Kritis Matematis Siswa Kelas IX SMP Negeri 3 Kota Tambolaka dalam Pemecahan Masalah pada Materi Bilangan Berpangkat Dan Bentuk Akar
}

\author{
Donatus Lalo ${ }^{1}$, Dekriati Ate ${ }^{2}$, Samuel Rex M. Making ${ }^{3}$ \\ 1,2,3Program Studi Pendidikan Matematika, Sekolah Tinggi Keguruan dan Ilmu Pendidikan Weetebula, Indonesia
}

\section{Article history \\ Received: 01 September 2018}

Revised: 10 November 2021 Accepted: 10 November 2021

*Corresponding Author: Donatus Lalo, STKIP Weetebula, Tambolaka, Indonesia;

Email:

donatustuslalo2@gmail.com

\begin{abstract}
Abstrak: Penelitian ini bertujuan untuk mendeskripsikan kemampuan berpikir kritis siswa dalam menyelesaikan soal bilangan berpangkat dan bentuk akar. Metode penelitian yang digunakan dalam penelitian ini yaitu metode penelitian kualitatif. Subjek dalam penelitian ini adalah seluruh siswa kelas IXA SMP Negeri 3 Kota Tambolaka dengan jumlah 35 siswa, dan subjek yang mendapat tindakan/treatment lebih lanjut yaitu 6 subjek, keenam subjek ini dipilih berdasarkan Kemampuan Awal Matematika kategori tinggi, kategori sedang dan kategori rendah. Masing-masing kategori dipilih 2 subjek yang akan mewakili 35 siswa tersebut. Jenis data yang dikumpulkan berupa data kualitatif yaitu hasil tes kemampuan berpikir kritis dan hasil wawancara. Data dianalisis berdasarkan indikator berpikir kritis yang telah ditetapkan oleh peneliti yang meliputi klarifikasi, assesmen penarikan kesimpulan, strategi dan taktik. Analisa data yang dilakukan melalui tahapan yaitu reduksi data, penyajian data dan verifikasi. Hasil analisis data diperoleh $11 \%$ siswa termasuk dalam kategori tinggi dengan kemampuan merinci pokok-pokok permasalahan, menggunakan rumus dengan benar dan tepat dalam menyelesaikan soal dan membuat kesimpulan dari jawabannya. $26 \%$ siswa termasuk dalam kategori sedang dengan kemampuan merinci pokok-pokok permasalahan, mampu menggunakan rumus dengan tepat dan benar. Sedangkan 63\% termasuk dalam kategori rendah karena hanya mampu merinci pokok-pokok permasalahan. Dari hasil tersebut menunjukkan bahwa kemampuan berpikir kritis siswa masih tergolong rendah.
\end{abstract}

Kata kunci: Kemampuan Berpikir Kritis Matematis Siswa, Bilangan Berpangkat dan Bentuk Akar

Abstract: This study aims to describe students creative thinking skills in solving numbers whit exponents and mecale root forms. The research used in this study is qualitative research methods. The subjects in ths study were all self-class IX-A SMP Negeri 3 Tambolaka City whit a total of 35 student, and subjects who received further treatment, namely 6 subjects, these six subjects were selected based on the high category of early mathematics ability, the moderate category and the low category. Each category selected 2 subjects who would represent the 35 student. Critical and interview result. Data were anayized based on critical thinking indicators that have been determined by the researchers which include clarification, assessment of conclusions, strategies and tactics. Data analysis was carried out through the stages of data reduction, data presentation and verification. The results of data analysis obtained $11 \%$ of students included in the category whit the ability to detail the main points of the problem, using the formula correctly and presicely in solving problems and making conclusions and answers $26 \%$ of students are in cluded in the medium category whit the ability to detail the main points of the problem, are able to use the formula correctly and correctly: While 63\% are included in the low category because only able to detail the main points of the problem. From these results, it shows that the critical thinking ability of is still relatively low.

Keywords: Student Mathematical Critical Thinking Ability, Numbers to powers and root forms. 


\section{Pendahuluan}

Menurut Ahmadi (2014:38), pendidikan adalah suatu cara hubungan manusia atas suasana yang berlangsung secara sadar dan terencana dalam rangka menumbuhkan segala kemampuannya, baik jasmani (kesehatan fisik), rohani (pikir, rasa, karsa, susunan, cipta, dan budi nurani) yang membangkitkan perubahan positif dan kesuksesan, baik psikologis, afektif, maupun psikomotorik yang berlangsung secara terus menerus untuk mencapai tujuan hidupnya. Pendidikan adalah suatu kebutuhan dasar bagi manusia dengan pendidikan yang diperoleh manusia menyiapkan diri dalam menjalani hidupnya.

Oleh karena itu pendidikan adalah suatu proses untuk membangun manusia dalam menumbuhkan potensi dirinya sehingga mampu memperoleh setiap perubahan yang terjadi. Salah satu bidang ilmu yang banyak aktif dalam bidang pendidikan adalah matematika permendiknas no. 22 menjelaskan alasan pentingnya mempelajari matematika adalah salah satu mata pelajaran yang bermakna dalam pendidikan. Matematika adalah bidang universal yang mendasari perubahan teknologi yang baru, memilik peranan penting dalam beragam ilmu. Untuk memiliki dan membangun teknologi di masa depan diperlukan keterampilan matematika yang kuat sejak awal, maka matematika dibimbing dari pendidikan dasar sampai perguruan tinggi. Hal tersebut juga diungkapkan oleh Rahmatillah (2017:51) bahwa pendidikan matematika berperan kegiatan dalam upaya dan membentuk manusia bermakna tinggi. Pembelajaran matematika di sekolah adalah sarana berpikir yang nyata, tanggap, inovatif, dan masuk akal.

Sedangkan Menurut Syahruddin (2018:1), mengatakan bahwa Pendidikan adalah keinginan manusia untuk hidupnya. Tanpa pendidikan, manusia tidak dapat membimbing menjadi lebih baik dan bermakna. Pendidikan akan terus dilakukan karena pendidikan tidak memahami peluang dan berproses selama hidup manusia.

Sternberg (1986) dan Lai dalam Rahayuningsih (2018:249) menyatakan bawah, berpikir kritis merupakan teknik batin, rencana, dan representasi yang digunakan orang untuk menyelesaikan suatu pertanyaan, menarik kesimpulan, dan mengamati konsep baru. menurut Mazer sendiri berpikir kritis adalah kemampuan untuk membentuk makna, mengekspresikan dan menilai alasan. Meskipun kemampuan berpikir kritis siswa dapat dilati dan dipelajari, tetapi yang terjadi di sekolah siswa mengetahui begitu saja apa yang guru sampaikan.

Perkins \& Murphy (Lestari, 2016:18) membagi tahap berpikir kritis dalam matematika menjadi 4 tahap sebagai berikut: klarifikasi, assesment, strategi dan taktik, dan penarikan kesimpulan. Tahap klarifikasi merupakan tahap menyatakan, mengklarifikasi, mendefinisikan masalah. Indikator: merinci pokok-pokok permasalahan. Aktivitas yang dilakukan adalah siswa dapat menentukan informasi yang diketahui dalam soal secara tepat dan jelas. Tahap asessment merupakan tahap menilai aspek-aspek seperti membuat keputusan pada situasi, mengemukakan fakta-fakta argumen atau menghubungkan masalah dengan masalah yang lain. Pada tahap ini digunakan beragam fakta yang mendukung atau menyangkal. Indikator: kemampuan memberikan alasan untuk menghasilkan kesimpulan yang benar. Aktivitas yang dilakukan adalah siswa dapat menentukan ide/konsep yang akan digunakan untuk menyelesaikan soal. Tahap inferensi menunjukkan hubungan antara sejumlah ide, menggambarkan kesimpulan yang tepat, menggeneralisasi. Indikator: menarik kesimpulan dengan jelas dan logis dari penyelidikan. Aktivitas yang dilakukan adalah siswa mampu membuat kesimpulan yang tepat dari masalah. Tahap strategi/ taktik merupakan tahap mengajukan, mengevaluasi sejumlah tindakan, menggambarkan tindakan yang mungkin, mengevaluasi tindakan dan memprediksi hasil tindakan. Indikator: menyelesaikan masalah dengan beragam alternatif penyelesaian berdasarkan konsep. Aktivitas yang dilakukan adalah siswa mengerjakan soal dengan runtut dan benar, siswa dapat menggunakan beragam alternatif dalam menyelesaikan soal.

Berdasarkan hasil observasi peneliti selama melaksanakan praktik pengalaman lapangan (PPL) di SMPN 3 Kota Tambolaka, rendahnya kemampuan berpikir kritis matematis juga dialami oleh siswa kelas IX-A SMP Negeri 3 Kota Tambolaka. Hal-hal yang membangkitkan rendahnya kemampuan berpikir kritis matematis siswa dalam pembelajaran matematika yaitu: 1) siswa belum mampu menggunakan rumus atau konsep yang tepat untuk menyelesaikan masalah (seperti saat guru bertanya kenapa harus menjawab atau menggunakan rumus seperti yang dikerjakan, siswa kurang mampu memberikan penjelasan) 2) Siswa masih bingung dalam memahami permasalahan yang diberikan. Dapat dilihat pada tabel 1. 1dimana nilai ulangan harian masih banyak siswa yang mendapat nilai kurang dari KKM. 
Tabel 1. Nilai Ulangan Siswa Kelas IX SMP Negeri 3 Kota Tambolaka

\begin{tabular}{|l|l|l|l|l|l|}
\hline \multirow{2}{*}{$\begin{array}{l}\text { Jumlah seluruh } \\
\text { siswa }\end{array}$} & \multirow{2}{*}{ KKM } & \multicolumn{2}{|l|}{ Jumlah Siswa } & Persentase Ketuntasan \\
\cline { 3 - 6 } & & $\mathrm{X}<75$ & $\mathrm{X} \geq 75$ & Tidak Tuntas & Tuntas \\
\hline 35 & 75 & 23 & 12 & $63,7 \%$ & $36,3 \%$ \\
\hline
\end{tabular}

Berdasarkan Tabel 1.1 dapat dilihat KKM untuk mata pelajaran matematika 75. Dari 32 siswa ada 20 siswa yang tidak memenuhi KKM jika dinyatakan dalam persen yaitu 63,7\% siswa yang tidak tuntas, sedangkan 12 siswa lainnya memenuhi KKM dan jika dinyatakan dalam persen siswa yaitu 36,3\% siswa yang tuntas.

Berdasarkan penelitian yang dilakukan oleh Lambertus (2009) tentang "Pentingnya belajar pengetahuan berpikir kritis dalam pembelajaran matematika di SD" menekan bawah berpikir kritis merupakan pengetahuan yang dimiliki oleh setiap orang, bisa diukur, dilatih dan dikembangkan. Berpikir kritis dalam pembelajaran matematika perlu dikembangkan mulai dari tahap pendidikan dasar, jika berpikir kritis dilatih terus - menerus dapat menjadi kebiasaan. Kebiasaan ini akan menjadi sikap dasar, dan pada akhirnya terbentuk diposisi berpikir kritis. penelitian yang dilakukan oleh Lambertus sebenarnya menyadarkan bahwa siswa SMP harus mampu berpikir kritis karena semenjak sekolah dasar telah dituntut agar siswa bias mampu berpikir kritis.

Berangkat masalah ini, terutama pada kemampuan berpikir kritis, penulis menilai bahwa sangat penting untuk membahas kemampuan berpikir kritis matematis siswa. Dari data yang ada, dapat dicari dan gali beberapa faktor yang mempengaruhi tinggi rendahnya kemampuan berpikir kritis siswa tersebut. Atas dasarnya pemikiran tersebut, peneliti analisis deskriptif dengan judul " Analisis Kemampuan Berpikir Kritis Matematis Siswa Kelas IX SMP Negeri 3 Kota Tambolaka pada Materi Bilangan Berpangkat dan Bentuk Akar Tahun Ajaran 2020/2021". Untuk mempermudah penulis dalam menganalisis hasil penelitian, maka penelitian ini difokuskan pada kegiatan menganalisis kemampuan berpikir kritis siswa dalam menyelesaikan soal bilangan berpangkat dan bentuk akar.

\section{Metode}

Jenis penelitian yang digunakan yaitu penelitian kualitatif dengan metodologi deskriptif yang bertujuan untuk mengetahui kemampuan peserta didik pada mata pelajaran matematika materi bilangan berpangkat dan bentuk akar kelas IX SMP Negeri 3 Kota Tambolaka. Bodgan dan Tailor (Moleong, 2010:4), mengemukakan bahwa proses penelitian yang menghasilkan data deskriptif berupa kata-kata lisan atau tertulis dari subjek dan perilaku yang diamati sebagai penelitian kualitatif. Penelitian ini dilaksanakan di SMP Negeri 3 Kota Tambolaka, Kecamatan Kota Tambolaka, Kabupaten Sumba Barat Daya. Alasan peneliti memilih sekolah ini karena di SMP Negeri 3 Kota Tambolaka adalah tempat praktik program pengalaman (PPL) pada semester sebelumnya, kelas IXA yang berjumlah 35 orang siswa, subjek yang mendapat tindakan sebanyak 6 orang dengan cara dipilih masing-masing 2 siswa berdasarkan kemampuan awal matematika tinggi, sedang, dan rendah. Instrumen yang digunakan dalam penelitian ini yaitu sol tes dan pedoman wawancara. Teknik pengumpulan data yang digunakan dalam penelitian ini meliputi: tes tertulis, wawancara, dokumentasi dan triangulasi. Sedangkan Untuk menganalisis data tersebut peneliti menggunakan model yang dikembangkan oleh Miles dan Huberman. Tahap-tahap analisis data dalam penelitian ini yaitu: reduksi data, penyajian data dan penarikan kesimpulan. Mereduksi data dimaknai sebagai kegiatan meringkas memilih hal-hal yang penting, memfokuskan pada hal-hal yang penting dan membuang yang tidak perlu. Reduksi data dalam penelitian ini dilakukan pada hasil tes tertulis dan hasil wawancara yang dilakukan kepada siswa. Data yang disajikan ialah data hasil pengerjaan soal-soal matematika berbentuk uraian dan data perolehan setelah dilakukan wawancara dengan subjek yang telah dipilih untuk diwawancarai. Data disajikan dalam bentuk tabel, uraian singkat atau narasi. Kesimpulan dalam penelitian ini adalah informasi baru yang ditemukan dan yang belum pernah ada sebelumnya. Informasi baru tersebut dapat berupa deskripsi atau gambaran suatu objek yang mula-mula belum jelas bila 
dikaji lebih lanjut menjadi jelas. Sehingga kesimpulannya jelas dan dipercaya. Berdasarkan analisis yang telah dilakukan maka dapat diperoleh kesimpulan tentang bagaimana gambaran tingkat kemampuan berpikir kritis siswa.

\section{Hasil dan Pembahasan}

Data penelitian yang digunakan dalam penelitian ini berupa hasil tes tertulis dan hasil wawancara subjek penelitian. Sebelum siswa diberikan tes kemampuan berpikir kritis siswa, terlebih dahulu siswa dibagi dalam 3 kategori berdasarkan Kemampuan Awal Matematika (KAM) yaitu siswa dengan kategori tinggi, sedang, dan rendah. Setelah siswa dikelompokkan berdasarkan kemampuan awal matematika (KAM), siswa diberikan tes kemampuan berpikir kritis siswa dalam menyelesaikan soal bilangan berpangkat dan bentuk akar. Berdasarkan penelitian yang telah dilaksanakan pada tanggal 6 April 2021 di kelas IX A SMP Negeri 3 Kota Tambolaka, diperoleh data dari hasil jawaban siswa tentang kemampuan berpikir kritis siswa dalam menyelesaikan soal. Adapun nilai persentase siswa dari tiga kategori pada diagram berikut:

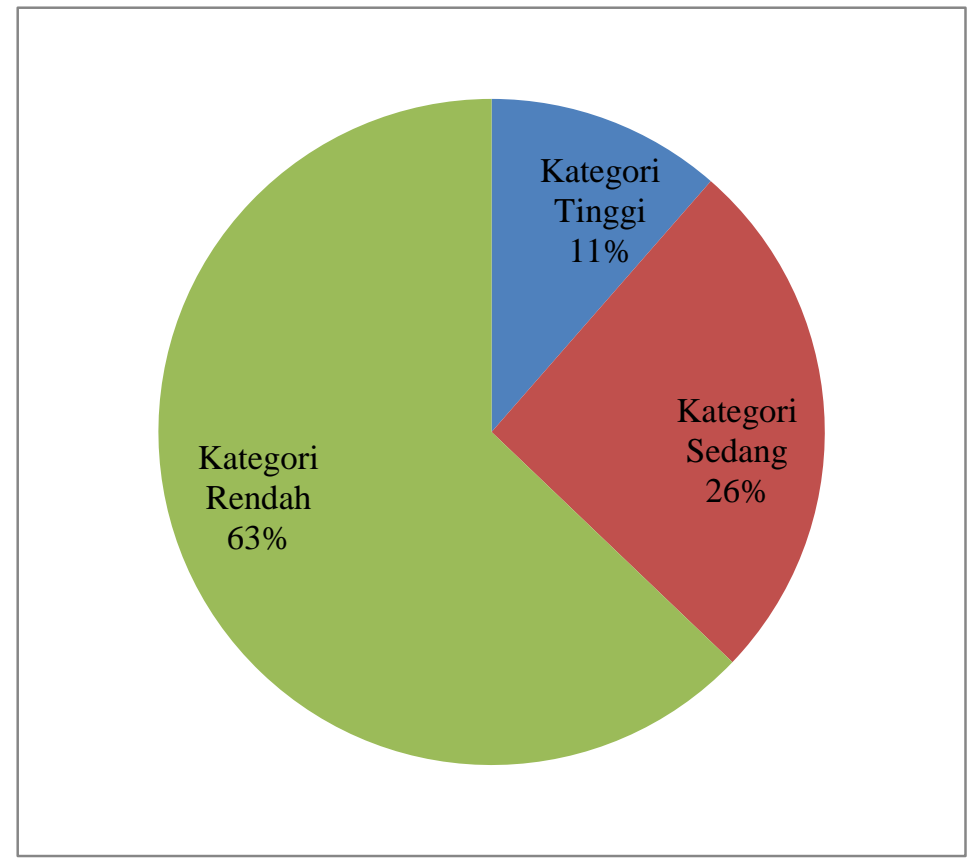

Gambar 1 Tingkat persentase kemampuan berpikir kritis siswa

Berdasarkan diagram lingkaran di atas maka hasil tingkat persentase kemampuan berpikir kritis siswa dalam tiga kategori, yaitu:

a. Kategori rendah persentasenya $63 \%$ dengan jumlah siswa yang melakukan kemampuan berpikir kritis siswa 22 orang. Seperti yang tertera pada tabel 4.3.

b. Kategori sedang persentasenya $26 \%$ dengan jumlah siswa yang melakukan kemampuan berpikir kritis siswa 9 orang. Seperti yang tertera pada tabel 4.3.

c. Kategori tinggi persentasenya $11 \%$ dengan jumlah siswa yang melakukan kemampuan berpikir kritis siswa 4 orang.

Berikut ini nilai persentase untuk setiap indikator kemampuan berpikir kritis untuk keseluruhan siswa sebagai berikut: 


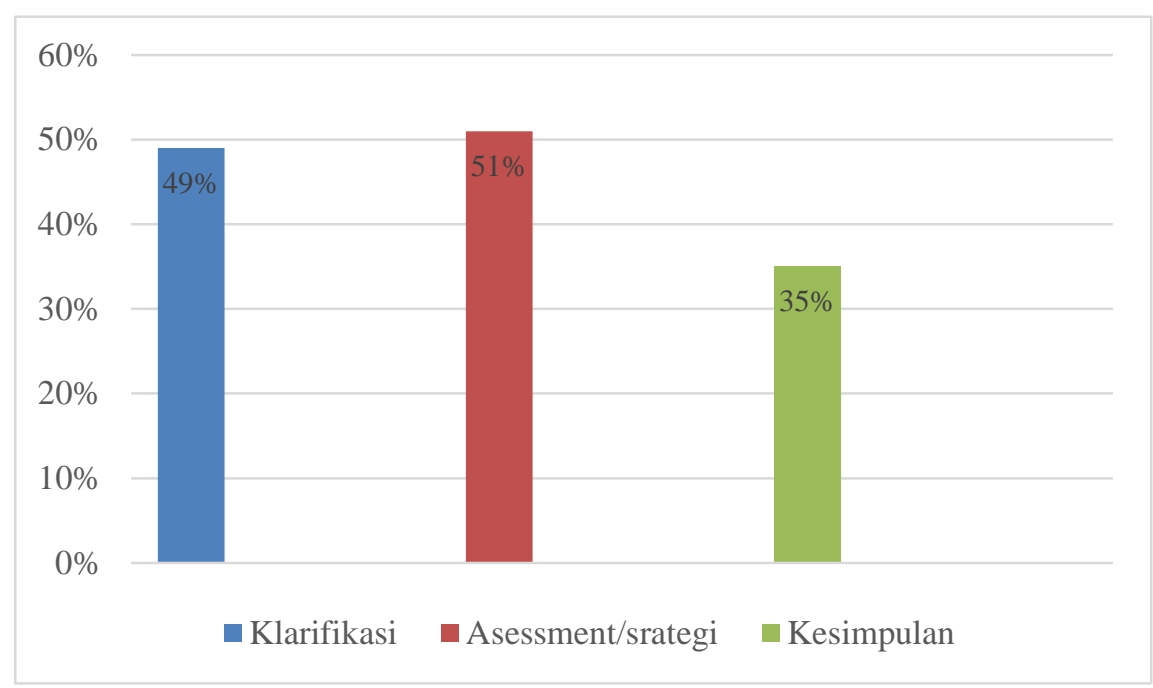

Gambar 2 Persentase Kemampuan Berpikir Kritis Siswa untuk Keseluruhan

Berdasarkan diagram persentase kemampuan berpikir kritis siswa untuk keseluruhan di atas maka, untuk tahap klarifikasi 49\%, tahap assessment/strategi dan taktik 51\%, dan tahap kesimpulan 35\%.

Berikut ini hasil jawaban subjek dalam menyelesaikan soal bilangan berpangkat dan bentuk akar.

\section{Data hasil tes jawaban siswa untuk kategori tinggi}



Gambar 3 Jawaban siswa untuk kategori tinggi

Dik : Air menetes sia - sia $=10^{-4} \frac{\text { liter }}{\text { detik }}$

Waktu: $10 \mathrm{jam}=10 \times 3600$ detik $=36000$ detik

Dit: Air yang terbuang?

Jawab: Banyak air terbuang 10 jam

$$
\begin{aligned}
& =10^{-4} \frac{1}{\text { ind }} \times 3600 \text { detik }=\frac{1}{10^{+}} \times 3600 \text { liter } \\
& =\frac{1}{10 \times 10 \times 10 \times 10} \times 3600 \text { liter } \\
= & \frac{1}{10000} \times 3600 \text { liter } \\
= & \frac{3600}{10000}=\frac{36}{10}=3,6 \text { liter }
\end{aligned}
$$

Jadi, air yang terbuang selama 10 jam yaitu 3,6 liter 
Dari hasil pekerjaan subjek di atas dapat dilihat bahwa subjek melalui tahap klarifikasi dengan merinci pokok-pokok permasalahan yaitu subjek menuliskan apa yang diketahui dalam soal dengan tepat yaitu air menetes sia-sia $10^{-4}$ liter per detik. Subjek 1 melalui tahap assesmen/strategi dan taktik karena subjek mampu menggunakan rumus dengan tepat dan menyelesaikannya dengan tepat dan benar sehingga subjek tersebut melalui tahap assesmen/strategi dan taktik. Subjek juga melalui tahap penarikan kesimpulan karena subjek membuat kesimpulan dengan benar. sehingga subjek tersebut melalui tahap kesimpulan.

Berikut adalah kutipan hasil wawancara antara peneliti dengan subjek 1 untuk soal nomor 1 adalah sebagai berikut:

$P$

: Apa yang diketahui pada soal no 1?

BFK : Yang diketahui yaitu air menetes sia-sia $=10^{-4}$ liter per detik

$P \quad$ :Apa yang ditanyakan dalam soal tersebut?

BFK : Berapakah air yang terbuang selama 10 jam?

$P \quad$ : Pengetahuan/konsep apa saja yang dibutuhkan untuk menyelesaikan masalah tersebut?

$B F K \quad:$ perpangkatan

$P \quad:$ :Tunjukkan mana yang dinamakan bilangan berpangkat?

BFK : Pangkat negatif empat.

$P \quad$ : Adakah cara lain agar dapat menyelesaikan soal tersebut?

BFK : Tidak ada pak guru.

$P \quad:$ : Apa kesimpulan dari jawaban yang telah kamu temukan?

BFK : Jadi, air yang terbuang selama 10 yaitu 3,6 liter

$P \quad:$ Apakah kamu yakin dengan jawaban yang telah diselesaikan?

BFK : Yakin pak guru

\section{Data hasil tes jawaban siswa untuk kategori sedang}



Gambar 4 Jawaban siswa untuk kategori sedang

Dik : Air menetes sia-sia dari suatu kran sebanyak $10^{-4}$ liter/detik

Waktu $: 10$ jam $=10 \times 3600$ detik $=36000$

Dit : Air yang terbuang?

Jawab :

Banyak air yang terbuang $10 \mathrm{jam}=10^{-4} \frac{\text { liter }}{\text { detik }} \times 36000$ detik

$$
\begin{aligned}
=\frac{1}{10^{4}} & =36000 \text { detik } \\
& =\frac{1}{10 \times 10 \times 10 \times 10} \times 36000
\end{aligned}
$$




$$
\begin{array}{r}
=\frac{1}{10000} \times 36000 \\
=3,6 \text { liter }
\end{array}
$$

Dari hasil pekerjaan subjek di atas dapat dilihat bahwa, subjek melalui tahap klarifikasi dengan merinci pokok-pokok permasalahan yaitu subjek menuliskan apa yang diketahui soal dengan benar yaitu air menetes sia - sia dari suatu kran air sebanyak $10^{-4}$ liter per detik. Subjek 3 melalui tahap assesmen karena subjek mampu menggunakan rumus dengan tepat dan menyelesaikan soalnya dengan benar sehingga subjek tersebut melalui tahap assesmen. Subjek juga tidak melalui tahap penarikan kesimpulan karena subjek tidak membuat kesimpulan sama sekali. sehingga subjek tersebut tidak melalui tahap kesimpulan.

Berikut adalah kutipan hasil wawancara antara peneliti dengan subjek 1 untuk soal nomor 1 adalah sebagai berikut:

$P \quad$ : Informasi apa yang ada dalam masalah tersebut?

LN $\quad$ : Air menetes sia-sia 10-4 dari suatu kran air dan waktu

$P \quad$ : Apa yang ditanyakan dalam soal tersebut?

LN $\quad$ : Air yang terbuang

$P \quad$ : Pengetahuan/konsep apa saja yang dibutuhkan untuk menyelesaikan masalah tersebut?

LN $\quad$ : Bilangan berpangkat

$P \quad$ : Apakah ada cara lain agar dapat menyelesaikan soal tersebut?

LN $\quad:$ Hmmmmm(diam).

$P \quad:$ Apa kesimpulan dari jawaban yang telah kamu temukan?

LN $\quad$ : Tidak tahu pak guru

$P \quad$ : Apakah kamu yakin dengan jawaban yang telah diselesaikan?

LN : Yakin.

\section{Data hasil tes jawaban siswa untuk kategori rendah}

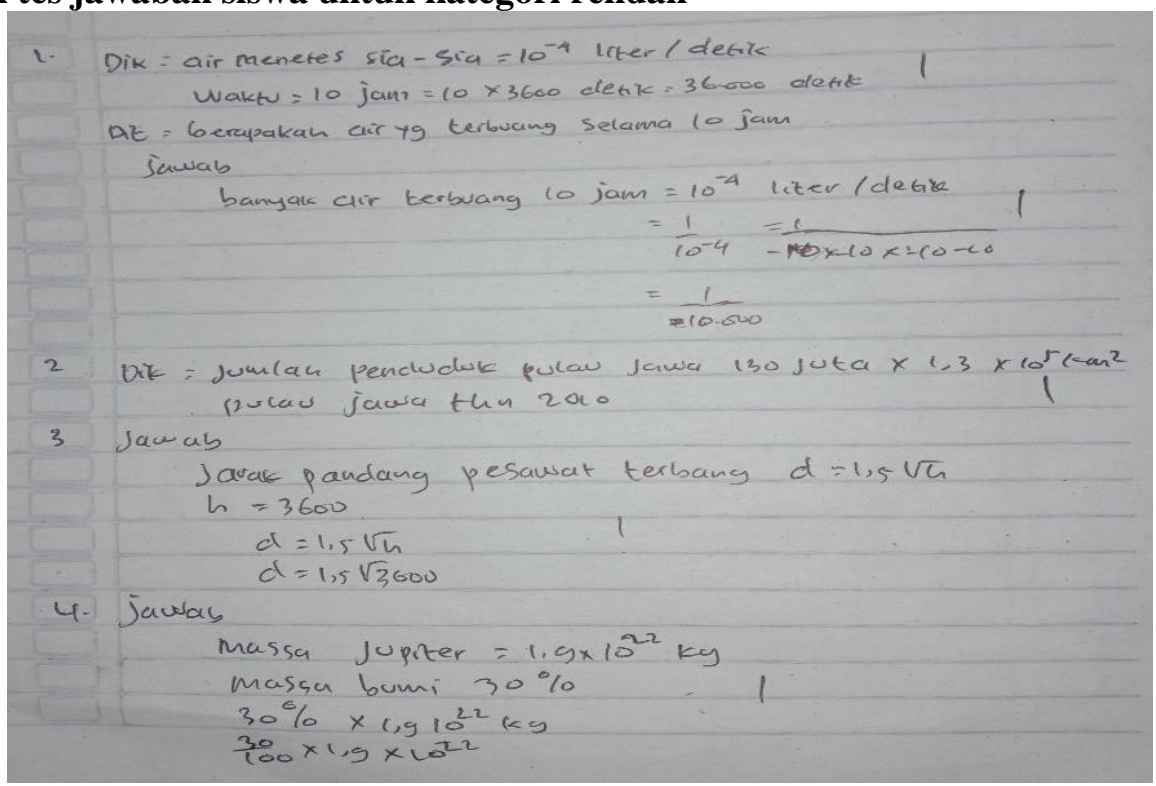

Gambar 5 Jawaban siswa untuk kategori rendah

1. Dik: Air yang menetes sia-sia $=10^{-4}$ liter/detik

Waktu $: 10$ jam $=10 \times 3600$ detik $=36000$ detik

Dit : Air yang terbuang?

Jawab : 


$$
\begin{aligned}
& \text { Banyak air terbuang } 10 \text { jam }=10^{-4} \frac{\text { liter }}{\text { detik }} \\
= & \frac{1}{10^{-4}} \\
= & \frac{1}{-10 x-10 x-10 x-10} \\
= & \frac{1}{10000}
\end{aligned}
$$

2. Dik: Jumlah penduduk pulau Jawa 130 juta $\times 1,3 \times 10^{5}$

Pulau jawa tahun 2010

3. Jawab :

Jarak pandang pesawat terbang $d=1,5 \sqrt{h}$

$$
\begin{aligned}
& \mathrm{h}=3600 \\
& \mathrm{~d}=1,5 \sqrt{h} \\
& \mathrm{~d}=1,5 \sqrt{3600}
\end{aligned}
$$

Dari hasil pekerjaan siswa di atas dapat dilihat bahwa, subjek 5 melalui tahap klarifikasi dengan merinci pokok-pokok permasalahan yaitu subjek menuliskan apa yang diketahui untuk soal nomor 1 yaitu air menetes sia-sia $=10^{-4}$ liter per detik. Namun subjek 5 tidak melalui asessmen/strategi dan taktik karena subjek tidak mampu menyelesaikan soal tersebut dengan menggunakan konsep yang benar. Sehingga subjek tersebut tidak melalui tahap asessmen/strategi dan taktik untuk semua soal S5 juga tidak membuat kesimpulan dari semua soal.

Berikut adalah kutipan hasil wawancara antara peneliti dengan subjek 5 untuk soal nomor 1-3 adalah sebagai berikut:

$P \quad$ : Dari soal yang diberikan, apakah kamu dapat menyelesaikan soal tersebut?

LD : Saya tidak bisa selesaikan pak guru.

$P \quad:$ : Menurut pendapat kamu apakah soal tersebut sulit?

LD $\quad$ : Menurut saya sulit.

$P \quad$ : Apakah kamu menyelesaikan soal

LD $\quad$ : Saya tidak bisa, karena saya tidak paham.

$P \quad$ : Dalam menyelesaikan soal, apakah kamu berusaha menyelesaikan perhitungan sampai menemukan jawabannya?

LD $\quad$ : Saya berusaha, tapi saya yakin salah

$P \quad$ : Apakah kamu sudah yakin dengan jawabanmu?

LD $\quad$ :Tidak yakin pak guru

$P \quad$ : Dari soal yang diberikan, soal mana yang paling sulit kamu pahami?

LD : Semua pak guru

$P \quad$ : Kenapa kamu tidak bisa mengerjakannya

LD $\quad:$ diam

\section{Kesimpulan}

Berdasarkan hasil penelitian dan pembahasan analisis kemampuan berpikir kritis siswa dalam menyelesaikan soal bilangan berpangkat dan bentuk akar dapat disimpulkan: Subjek dengan Kemampuan Awal Matematika tinggi dalam menyelesaikan soal mampu merinci pokok-pokok permasalahan dengan menuliskan apa yang diketahui pada soal, kemudian mampu menggunakan konsep atau rumus dengan benar dan juga mampu membuat kesimpulan. Subjek dengan Kemampuan Awal Matematika sedang dalam menyelesaikan soal mampu merinci pokok-pokok permasalahan dengan menuliskan apa yang diketahui pada soal, kemudian mampu menggunakan rumus dengan benar dan tepat dalam menyelesaikan soal, dan subjek juga mampu membuat kesimpulan dari jawabannya dengan benar. Subjek dengan KAM rendah dalam 
menyelesaikan soal mampu merinci pokok-pokok permasalahan dengan menuliskan apa yang diketahui pada soal, untuk tahap assesmen siswa kurang mampu dalam menggunakan rumus dengan tepat, dan siswa kurang mampu membuat kesimpulan.

\section{Saran}

Berdasarkan hasil penelitian, maka penulis ingin mengajukan beberapa saran yaitu: dapat dijadikan sumbangsih pemikiran untuk bisa selalu meningkatkan kemampuan berpikir kritis siswa, tidak hanya dalam mata pelajaran matematika, tetapi juga untuk mata pelajaran lainnya. Sebagai masukan atau informasi tentang bagaimana kemampuan berpikir kritis siswa di sekolah dalam menyelesaikan suatu masalah matematika yang diberikan, sehingga bisa menjadi acuan untuk mencari alternatif solusi dalam meningkatkan kemampuan berpikir kritis. Meningkatkan kesadaran untuk berpikir lebih kritis lagi dan mendapat gambaran atau pemaparan kemampuan berpikir kritis untuk dijadikan pembanding pada penelitian lainnya, terlebih khusus untuk kemampuan berpikir kritis menurut teori Murphy \& Perkins.

\section{Daftar Pustaka}

Ahmadi, Rulam. 2014. Pengantar pendidikan. Yogyakarta: AR-RUZZ MEDIA.

Lambertus. 2009. Pentingnya melatih keterampilan berpikir kritis siswa dalam pembelajaran matematika Di SD. Forum pendidikan.28(2).

Lestari, Sri W. 2016. Analisis Proses Berpikir Kritis Siswa dalam Pemecahan Masalah Matematika pada Pokok Bahasan Himpunan Ditinjau dari Tipe Kepribadian Ekstrovert dan Introvert Siswa Kelas VII SMPN 2 Sumber Cirebon. Di httpps: //www.google.co.id/5915/1/1235110090. (akses 18 Februari 2019).

Moleong. (2012). Metode Penelitian Kualitatif Edisis Revisi. Bandung: Remaja Rosdakarya

Rahmatillah, Siti., Hobri., Oktavianingtyas, Erwin. 2017. Tingkat kemampuan berpikir kritis siswa dalam menyelesaikan soal Barisan dan Deret Aritmatika Di SMAN 5 Jember.Jurnal kadikma.8(2):51 -60 di http://unej.ac.id. 